\title{
Singularidades e Coletividades
}

Mariana Baruco Machado Andraus ${ }^{1}$

O volume 5, número 2 da Conceição/Conception apresenta a temática Singularidades e Coletividades na pesquisa e na criação em artes da cena, bem como suas transposições, perscrutando manifestações que, de singulares, ampliam-se para um coletivo, bem como aquilo que a partir de um coletivo é singularizado.

O artigo de Carla Vendramin, Lucas Reis Velho e Wagner Ferraz, intitulado "Diversos Corpos Dançantes: uma proposta de improvisação e dança na comunidade", abre a temática abordando a singularidade dos corpos e a coletividade do processo na criação de um espetáculo do projeto Diversos Corpos Dançantes, vinculado ao projeto de pesquisa "A Dança com Pessoas com Deficiência e Grupos de Habilidades Mistas", desenvolvido no Curso de Licenciatura em Dança da Universidade Federal do Rio Grande do Sul e coordenado pela Professora Carla Vendramin.

Em "Musings on Colletctivity", Holly Cavrell reflete sobre o que define o coletivo, discutindo a coletividade na dança e políticas de controle. Discorre sobre como essas relações se dão em Nova Iorque, onde viveu, e fala também sobre sua experiência com coletivos de dança e sobre como as relações hierárquicas se modificaram nos últimos vinte anos.

No artigo "Arte na rua e desdobramentos", os autores Débora Souto Allemand e Eduardo Rocha discutem as relações de troca e reconstituição entre os cidadãos a partir do contexto dado pelo espaço urbano, entendendo as cidades como importantes espaços de subjetivação. Com base na concepção pós-moderna de democratização da arte, que leva à escolha por espaços alternativos ao teatro como forma de ir para a rua e, com isso, fazer política, tem-se coletivos de artistas atuando com happenings e performances no espaço urbano, o que gera mudanças para aqueles que caminham na rua - os pedestres, entendidos como espectadores emancipados -, provocando novas maneiras de estar na cidade.

Marisa Martins Lambert contribui para a temática com o artigo "Irmgard Bartenieff: uma herança de conectividade", no qual enfoca o percurso singular de Bartenieff para chegar à formulação da visão de corpo e movimento postulada pela
1.

Docente do Departamento de Artes Corporais do Instituto de Artes da Universidade Estadual de Campinas. Coordenadora do Programa de Pós-Graduação em Artes da Cena. Contato: m_andraus@iar.unicamp.br ORCID: http://orcid.org/ 0000-0003-4460-8555 
artista e educadora somática, visão esta que se modula a partir de referências do coletivo, expressas na ideia de conectividade.

$\mathrm{O}$ artigo "Performance social versus arte: hibridações poéticas", de Elder Sereni Ildefonso e Gabriela Fregoneis, discute tanto os conceitos de hibridismo nas artes e de liminaridade na relação destas com o espaço urbano (para isso, analisam a performance Mugre, de Rosemberg Sandoval, e o Proyecto Filoctetes, do grupo El Periférico de Objectos), como as relações entre singular e coletivo que se estabelecem nessas interações. Partindo de Oliveira, que diz que "a multidão é a forma permanente da existência social e política do coletivo" (OLIVEIRA, 2007), o texto lança a proposição de que o sujeito "assume um corpus coletivo mediado pela percepção em meio aos diálogos propostos pelos que ali se encontram".

Em Temas Livres, Andrea Copeliovitch discorre, no artigo "O trabalho do ator sobre si mesmo", a respeito da visão de Stanislavski sobre o trabalho do ator, relacionando o acontecimento da vida no palco com a temporalidade da ação, desde a ação cotidiana até aquela que se apresenta à cena, constituindo o repertório de vivências do ator pautado na memória, na ação, na linguagem e no silêncio.

Paulo Baeta, no artigo "Introdução à metodologia didática em dança de Rolf Gelewski", elabora suas memórias como ex-aluno do fundador do primeiro curso superior de dança do país, na Universidade Federal da Bahia, explicando pressupostos do método de Rolf Gelewski e descrevendo exemplos de exercícios, alguns dos quais constantes de apostilas de curso e/ ou livros com edições já esgotadas.

O artigo "Caminhos no método BPI: a incorporação da personagem Sete Ondas a partir da pesquisa de campo com baianas de escolas de samba e com o congado", de Maria Julia Alves Maranzato e Larissa Sato Turtelli, relata a experiência vivida pela primeira autora junto ao coletivo de baianas de escolas de samba da cidade de Jundiaí e na festa do Congado na comunidade dos Arturos, em Contagem-MG, tendo em vista a experiência de incorporação da personagem Sete Ondas a partir das experiências de campo.

Encerrando a seção Temas Livres, Lucas de Carvalho Larcher Pinto, no artigo A poética da morte: formas animadas.., imaginação, projeção(ões) e infâncias em cena, versa sobre possíveis aproximações entre o Teatro de Formas Animadas e o Teatro Infanto-Juvenil na experiência de criação e apresentações do espetáculo $O$ Mensageiro do Rei, em Uberlândia-MG, no ano de 2014. Expõe exemplos, reflete e discute acerca de questões que se revelaram em decorrência da presença da animação na peça, propondo possibilidades para que sejam redimensionadas para outros espetáculos e/ou contextos. 